\title{
Effect on fertility of female mice of the transfer of lymphocytes from females previously immunized with mouse spermatozoa
}

\author{
H. Tinneberg*, R. Birke and L. Mettler \\ Department of Obstetrics and Gynecology and Midwifery School, \\ Christian-Albrechts-Universitat, 4 Hegewischstrasse, D23 Kiel 1, West Germany
}

\begin{abstract}
Summary. To examine the influence of cellular immunity to spermatozoa on the fertility of inbred mice, leucocytes were transferred from other female mice that had been immunized with spermatozoa. Both syngeneic and allogeneic systems were investigated. The cellular immune reaction was estimated using a footpad swelling test before and after the cell transfer. There was a significant increase of the paw thickness and a statistically significant reduction in fertility only for $\mathrm{C} 3 \mathrm{H}$ mice immunized with C57BL spermatozoa.
\end{abstract}

\section{Introduction}

A number of authors have indicated the relevance of sperm antibodies in the field of immunoreproduction (Landsteiner, 1899; Metchnikoff, 1899; Metalnikoff, 1900; Wilson, 1954; Rümke \& Hellinga, 1959; Franklin \& Dukes, 1964; Boettcher, Hay, Kay, Baldo \& Roberts, 1970; Jones, 1971; Shulman, 1974, 1976; Mettler, 1977). There appears to be a correlation between the frequencies of antisperm antibodies and fertility (Shulman, 1972, 1974; Rümke, 1972; Mettler, 1977). However, little reference has been given to the cellular immune response to sperm antigens. In spite of several reports concerning cellular immunity to spermatozoa (Gordon, Barsales, Westermann \& Mumford, 1971; Mumford, Barsales, Ball \& Gordon, 1971; Shulman, 1972, 1974; Mettler, 1974) the significance of the cellular immune reaction to sperm antigens remains unclear.

In the present studies, we examined the effects of transfer of mouse leucocytes sensitized to spermatozoa on the fertility and fecundity of virgin mice.

\section{Materials and Methods}

Mice

Inbred mice of the $\mathrm{C} 3 \mathrm{H} / \mathrm{Tif} / \mathrm{Bom}$ and $\mathrm{C} 57 \mathrm{BL} / 6 \mathrm{~J}$ Bom strains (referred to hereafter as $\mathrm{C} 3 \mathrm{H}$ and C57BL) were used (G. I. Bomhold Ltd, 8680 Ry, Denmark). Female mice were housed in groups of 4-6 and males of proven fertility were added (1/cage) when necessary. Food and water were supplied ad libitum.

\section{Spermatozoa and erythrocytes}

Spermatozoa, obtained by forcing phosphate-buffered saline (PBS) $(0.15 \mathrm{M}-\mathrm{NaCl}, 0.1 \mathrm{M}$ phosphate, $\mathrm{pH}$ 7.2) through the excised ductus deferens, were washed at $400 \mathrm{~g}$ for $5 \mathrm{~min}$ and

* Present address: Department of Biological Sciences, University of Newcastle, New South Wales 2308, Australia. 
brought to a concentration of 1.6-2.4 $\times 10^{6}$ spermatozoa/ml in PBS, or in Freund's Complete Adjuvant (FCA) diluted 1:1 with PBS. Erythrocytes from whole mouse blood were washed 3 times with PBS and suspended to a concentration of $1 \%$ in PBS or in FCA diluted $1: 1$ with PBS.

\section{Footpad swelling test}

The method of Bonta \& De Vos (1965) and Kerckhaert, van den Berg \& Willers (1974), measuring the footpad swelling after injection, was followed because of its technical simplicity. The female mice were injected in the planta pedis with $0.1 \mathrm{ml}$ of a $2 \%$ suspension of spermatozoa. Before the injection and $24 \mathrm{~h}$ after the injection, the thickness of the footpad was measured with a micrometer.

\section{Leucocyte fractionation}

Leucocytes were obtained from the spleens of mice immunized with spermatozoa by rinsing the spleens in Hank's medium and then passing the suspension through a sieve. After passing the leucocytes through a leukopak column, the non-adherent cells were collected (Julius, Simpson \& Herzberg, 1973; Brown \& Greaves, 1974). For the control experiments, leucocytes from the spleens of the animals sensitized with erythrocytes were prepared in the same way. The leucocytes obtained from 2 spleens were transferred via intraperitoneal injection to one virgin mouse of the same strain as that of the mice from which the leucocytes were taken. The viability of the leucocytes was estimated by staining with trypan blue.

\section{Results}

\section{Experiment 1}

The normal fertility of the mice in inter- and intra-strain matings was determined from $\mathrm{C} 3 \mathrm{H}$ $q \times \mathrm{C} 3 \mathrm{H} \delta^{7} ; \mathrm{C} 3 \mathrm{H} q \times \mathrm{C} 57 \mathrm{BL} \delta^{7}$; $\mathrm{C} 57 \mathrm{BL} q \times \mathrm{C} 57 \mathrm{BL} \delta$; and $\mathrm{C} 57 \mathrm{BL} q \times \mathrm{C} 3 \mathrm{H} \delta^{\pi}$. There were 25 females in each group and 1 male to 5 females, and $95 \%$ were fertile.

Table 1. Numbers of mice becoming pregnant and their litter sizes after immunization against spermatozoa or erythrocytes suspended in PBS or Freund's Complete Adjuvant (FCA)

\begin{tabular}{|c|c|c|c|c|c|c|c|c|}
\hline \multirow[b]{4}{*}{. } & \multicolumn{8}{|c|}{ Sperm donor and sire } \\
\hline & \multicolumn{4}{|c|}{$\mathrm{C} 3 \mathrm{H}$} & \multicolumn{4}{|c|}{$\mathrm{C} 57 \mathrm{BL}$} \\
\hline & \multicolumn{2}{|c|}{ PBS } & \multicolumn{2}{|c|}{ FCA } & \multicolumn{2}{|c|}{ PBS } & \multicolumn{2}{|c|}{ FCA } \\
\hline & Sperm. & RBC & Sperm. & RBC & Sperm. & $\mathbf{R B C}$ & Sperm. & RBC \\
\hline \multicolumn{9}{|l|}{$\mathrm{C} 3 \mathrm{H}$} \\
\hline No. of females & 10 & 9 & 9 & 9 & 10 & 10 & 10 & 9 \\
\hline No. pregnant & 4 & 9 & 7 & 9 & $2^{*}$ & 10 & $0^{*}$ & 9 \\
\hline \multicolumn{9}{|l|}{ Litter size } \\
\hline (mean \pm s.e.m.) & $\begin{array}{c}5.75 \\
\pm 1.09\end{array}$ & $\begin{array}{c}7.22 \\
\pm 0.94\end{array}$ & $\begin{array}{c}5.00 \\
\pm 1.56\end{array}$ & $\begin{array}{c}5.89 \\
\pm 1.37\end{array}$ & $(5,2)$ & $\begin{array}{c}6.7 \\
\pm 1.68\end{array}$ & - & $\begin{array}{c}5.89 \\
\pm 1.45\end{array}$ \\
\hline \multicolumn{9}{|l|}{ C57BL } \\
\hline No. of females & 8 & 10 & 10 & 8 & 9 & 10 & 9 & 10 \\
\hline No. pregnant & 7 & 10 & 7 & 8 & $3^{*}$ & 10 & $0^{*}$ & 9 \\
\hline \multicolumn{9}{|l|}{ Litter size } \\
\hline (mean \pm s.e.m. $)$ & $\begin{array}{c}7.85 \\
\pm 1.13\end{array}$ & $\begin{array}{c}7.7 \\
\pm 0.9\end{array}$ & $\begin{array}{c}6 \cdot 14 \\
\pm 1.12\end{array}$ & $\begin{array}{c}5.25 \\
\pm 0.97\end{array}$ & $\begin{array}{c}6.67 \\
\pm 0.39\end{array}$ & $\begin{array}{c}6.9 \\
\pm 0.7\end{array}$ & - & $\begin{array}{c}6.56 \\
\pm 1.06\end{array}$ \\
\hline
\end{tabular}

* $P<0.05$ compared with control value with $\mathrm{RBCs}$ ( $\chi^{2}$ test). 


\section{Experiment 2}

Virgin female mice of the $\mathrm{C} 3 \mathrm{H}$ and $\mathrm{C} 57 \mathrm{BL}$ strains were immunized with spermatozoa from $\mathrm{C} 3 \mathrm{H}$ or $\mathrm{C} 57 \mathrm{BL}$ males by means of 8 intraperitoneal injections, 3-4 days apart. Control groups received $1 \%$ erythrocyte suspensions. The injection volume was $0.5 \mathrm{ml}$. The mice were mated 1 week after the last injection and killed 18 days later. The average body weight was $35 \mathrm{~g}$.

A statistically significant reduction in fertility was observed only in the mice immunized with spermatozoa from males of the C57BL strain in comparison with the equivalent control groups immunized with erythrocytes (Table 1).

When Freund's Complete Adjuvant was used as the suspension medium for the C57BL spermatozoa, none of the mice became pregnant. Since immunization with spermatozoa suspended in PBS also produced a statistically significant reduction in fertility, PBS was used as the suspension medium in subsequent experiments.

\section{Experiment 3}

Virgin mice (30/group) were immunized against spermatozoa as described for Exp. 2. Control groups were also similar. After 4 weeks of immunization, the cellular sensitization against sperm antigens was evaluated by the footpad swelling test. There was a statistically

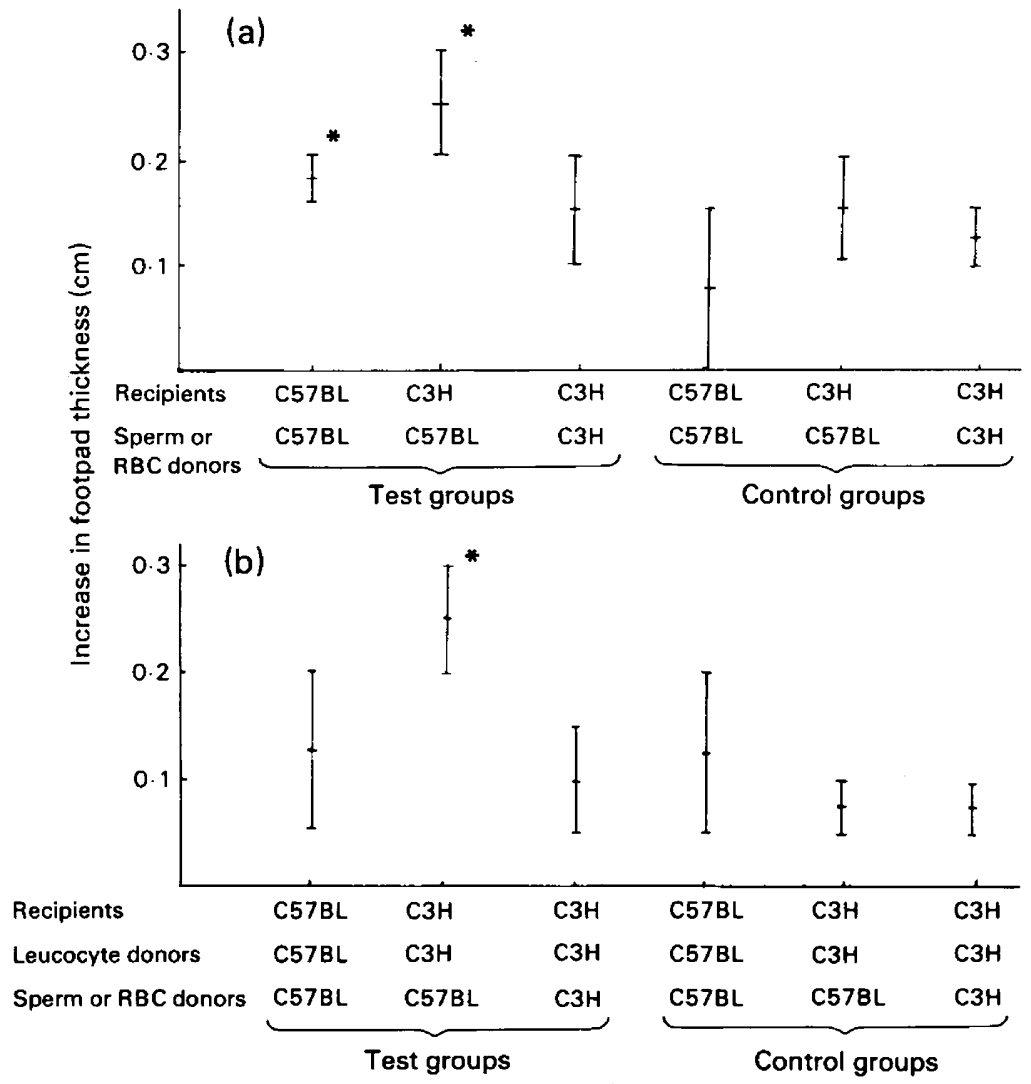

Text-fig. 1. Results (means with $95 \%$ confidence limits) of footpad swelling tests in female mice immunized with spermatozoa from mice of different strains (a) before and (b) after cell transfer from female mice immunized with spermatozoa. In (a) $\mathrm{N}=30$ mice/group; in (b) $\mathrm{N}=15$ mice/ group. Values in the groups marked by an asterisk $\left(^{*}\right)$ were significantly different from the equivalent control group, $P<0.01$ (Wilcoxon test). 
Table 2. Numbers of female mice (15/group) becoming pregnant after receiving lymphocytes from females of the same strain but immunized with spermatozoa

\begin{tabular}{cccccc}
\hline & \multicolumn{4}{c}{ Strain of sperm donor and sire } \\
\cline { 2 - 3 } \cline { 5 - 6 } $\begin{array}{c}\text { Strain of female used as } \\
\text { cell donor and as recipient }\end{array}$ & $\begin{array}{c}\text { Spermatozoa } \\
\text { in PBS }\end{array}$ & $\begin{array}{c}\text { RBC } \\
\text { control }\end{array}$ & $\begin{array}{c}\text { Spermatozoa } \\
\text { in PBS }\end{array}$ & $\begin{array}{c}\text { RBC } \\
\text { control }\end{array}$ \\
\hline C3H & 8 & 10 & & $5^{*}$ & 10 \\
C57BL & NT & NT & & 8 & 11 \\
\hline & $N T=$ not tested. \\
$P<0.05$ compared with control $\left(\chi^{2}\right.$ test $)$.
\end{tabular}

significant increase of the footpad thickness in comparison to the control group only when spermatozoa from C57BL mice were used (Text-fig. 1a).

All 180 mice ( 3 experimental and 3 control groups) were killed 1 week later and the spleens collected. After washing the spleen cells through a leukopak column, the non-adherent cells (which had a viability of $90 \%$ ) were transferred syngeneically to virgin mice and another footpad swelling test was performed 1 week later. A statistically significant increase of paw thickness compared with the control group was observed only in $\mathrm{C} 3 \mathrm{H}$ mice which had received cells from C3H females immunized with C57BL spermatozoa (Text-fig. 1b).

Only $\mathrm{C} 3 \mathrm{H}$ mice which received $\mathrm{C} 3 \mathrm{H}$ cells sensitized against $\mathrm{C} 57 \mathrm{BL}$ spermatozoa showed a statistically significant reduction in fertility (Table 2 ).

\section{Discussion}

There is increasing evidence that in women a relationship exists between a positive response to sperm antigens and sterility (Rose, Hjort, Rümke, Harper \& Vyazov, 1976; Boettcher, Hjort, Rümke, Shulman \& Vyazov, 1977). The relative importance of the cellular and the humoral components of the immune response in such a relationship is unknown at present.

From our present studies with mice it was concluded that immunization with spermatozoa is able to cause a statistically significant reduction in fertility. For $\mathrm{C} 3 \mathrm{H}$ females immunized with C57BL spermatozoa, the reduction in fertility could be related both to sperm-specific antigens and to different histocompatibility antigens, but for C57BL females immunized with C57BL spermatozoa a fertility reduction must be considered as a reaction to specific sperm antigens, since males and females have the same histocompatibility antigens. These antigens might be sperm-specific or sex-related, e.g. like the $\mathrm{H}-\mathrm{Y}$ antigen. The $\mathrm{H}-\mathrm{Y}$, or male specific, antigen was one of the first antigens to be detected on mouse spermatozoa (Vojtiskova \& Polackova, 1971) and Goldberg, Boyse, Bennet, Scheid \& Carswell (1971) have shown that the H-Y antigen of C57BL mice is of higher immunological potency than the corresponding antigen of $\mathrm{C} 3 \mathrm{H}$ mice.

The immunization schedule that we used was clearly effective in inducing an immune response, and was also effective in inducing a reduction in fertility in some cases, but these experimental results could not distinguish whether the reduction in fertility was due to the demonstrable cell-mediated immune reaction, as indicated by the footpad swelling, or to a humoral immune reaction which was not measured. However, the results obtained from a series of similar experiments in which serum transfer experiments were performed after sensitization of females against spermatozoa indicated that syngeneic serum transfer from $\mathrm{C} 3 \mathrm{H}$ or $\mathrm{C} 57 \mathrm{BL}$ virgin females caused a statistically significant fertility reduction (Birke, Tinneberg, Mettler \& Semm, 1976; Birke, 1978). The reduction in fertility induced by immunization against spermatozoa in the $\mathrm{C} 3 \mathrm{H}$ and $\mathrm{C} 57 \mathrm{BL}$ mouse strains therefore appears to have a cellular and a 
humoral component, with a seemingly higher influence of the humoral component on the fertility reduction.

We thank Professor B. Boettcher and Dr T. K. Roberts from the Department of Biological Sciences in Newcastle, Australia, for help with the manuscript. The investigation was supported by the Deutsche Forschungsgemeinschaft, SFB 111.

\section{References}

Birke, R. (1978) Die Bedentung der Sensibilisierung gegen Spermatozoen im humoralen System der Maus für die Fertilität. Doctoral Dissertation, Kiel.

Birke, R., Tinneberg, H., Mettler, L. \& Semm, K. (1976) Beziehungen zwischen dem Auftreten von SpermaantiKörpern und der Anderung des Reproduktions muslers nach Immunisierung mit Spermatozoen bei Inzuchtm̈äusen. Zuchthygiene 11, 80.

Boettcher, B., Hay, I., Kay, D.J., Baldo, B.A. \& Roberts, T.K. (1970) Sperm agglutinating activity in some human sera. Int. J. Fertil. 15, 143-158.

Boettcher, B., Hjort, T., Rümke, P., Shulman, S. \& Vyazov, O.E. (1977) Auto- and iso-antibodies to antigens of the human reproductive system. Acta path. microbiol. scand., Suppl. 258, 5-69.

Bonta, I.L. \& De Vos, EJ. (1965) The effect of estriol16,17-dihemisuccinate on vascular permeability as evaluated in the rat paw edema test. Acta endocr., Copenh. 49, 403-411.

Brown, G. \& Greaves, M.P. (1974) Cell surface markers for T- and B-lymphocytes. Eur. J. Immunol. 4, 302310.

Franklin, P.R. \& Dukes, C.D. (1964) Further studies on sperm agglutinating antibody and unexplained infertility. J. Am. med. Ass. 190, 682-683.

Goldberg, E.H., Boyse, E.A., Bennet, D., Scheid, N. \& Carswelt, E.A. (1971) Serological demonstration of $\mathrm{H}-\mathrm{Y}$ (male) antigen on mouse sperm. Nature, Lond. 232, 478-480.

Gordon, H.L., Barsales, P.B., Westermann, E.L. \& Mumford, D.M. (1971) Microlymphocyte transformation studies with seminal antigen. II. Observations in male patients with spermagglutinating antibodies. J. Urol. 105, 858-862.

Jones, W.R. (1971) Immunological aspects of fertility. Med.J. Aust. 2, 486-489.

Julius, M.H., Simpson, E. \& Herzberg, L.A. (1973) A rapid method for the isolation of functional thymusderived murine lymphocytes. Eur. J. Immunol. 3, 645-649.

Kerckhaert, J.A.M., van den Berg, G.J. \& Willers, J. (1974) Influence of cyclophosphamide on the delayed hypersensitivity of the mouse. Annls Immunol. $125 \mathrm{c}$, 415-426.
Landsteiner, K. (1899) Zur Kenntwis der spezifisch auf Blutkörperchen wirkenden Sera. Zentbl. Bakt. Parasitkde 25, 546-549.

McLaren, A. (1964) Immunological control of fertility in female mice. Nature, Lond. 201, 582-585.

Metalnikoff, F. (1900) Etudes sur la spermatoxine. Annls Inst. Pasteur 14, 577-589.

Metchnikoff, E. (1899) Etudes sur la resorption des cellules. Annls Inst. Pasteur 13, 737-770.

Mettler, L. (1974) Immunologie in der Sterilität. Diagnostik 7, 1-14.

Mettler, L. (1977) Immunologie der Weiblichen Sterilitat: Sensibilisierung gegen Sperma antigene im humoralen und zellularen Immunsystem der Frau. Fortschr. Fertilitatsforsch. 4, 10-25.

Mumford, D.M., Barsales, P.B., Ball, U.D. \& Gordon, H. (1971) Microlymphocyte transformation studies with seminal antigen. 1. Technique and patterns of responsiveness to autologous and allogenic semen from normal and infertile male subjects. J. Urol. 105 , $858-862$.

Rose, N.R., Hjort, T., Rümke, P., Harper, M.J.K. \& Vyazov, O. (1976) Techniques for detection of isoand auto-antibodies to human spermatozoa. Clin. exp. Immunol. 23, 175-199.

Rümke, P. (1972) Autoantibody formations against spermatozoa caused by extravasation of spermatozoa into the interstitium of the epididymis of aged men. Int. J. Fertil. 17, 86-88.

Rümke, P. \& Hellinga, G. (1959) Autoantibodies against spermatozoa in sterile men. Am. J. Clin. Path. 32, 357-363.

Shulman, S. (1972) Immunological barriers to fertility. Obstet. Gynec. Survey 27, 553-606.

Shulman, S. (1974) Tissue specificity and autoimmunity. Mol. Biol. Biochem. Biophys. 16, 71-100.

Shulman, S. (1976) Treatment of immune male-infertility with methylprednisolon. Lancet ii, 1243.

Vojtiskova, M. \& Polackova, M. (1971) Androgenic activity and expression of male-specific antigen and androgenic activity. Folia biol. 17, 200-203.

Wilson, L. (1954) Sperm agglutinins in human semen and blood. Proc. Soc. exp. Biol. Med. 85, 652-655.

Received 5 September 1979 